\title{
Effects of Composted and Vermicomposted Sugarcane Industry Wastes and Farm Manure on Tomato Quality and Yield
}

\author{
Rahmatullah Shah $^{1 \mathrm{a}}$, Muhammad Abid ${ }^{1 \mathrm{~b}}$, and Muhammad Farooq Qayyum ${ }^{1 \mathrm{c}}$ \\ RECEIVED ON 03.12.2018, ACCEPTED ON 19.02.2019
}

\begin{abstract}
A field study was conducted to signify the use of sugarcane industrial and dairy farm wastes through composting and vermi-composting and application to tomato (Lycopersicum esculentum $L$ ) crop to evaluate any effects on growth, yield and fruit quality. Composts and vermi-composts of FM (Farm Manure), SB (Sugarcane Bagasse), SP (Sugarcane Pressmud), mixture of SB $\times$ SP $\times$ SE [sugarcane effluent (1:1:1)] @ 10 t ha${ }^{1}$, respectively were applied before transplanting of nursery. The fertilizers NPK @ 81-76-76 kg ha-1 were also applied in all plots. Overall, there were significant $(\mathbf{p} \leq \mathbf{0 . 0 5})$ impacts of treatments on agronomic and fruit quality traits. Plant height, stem diameter, number of leaves, number of fruits and yield were increased by 37 , 67, 62, 59 and 24\% with FMVC (Farm Manure Vermi-Compost) treatment over control. There was 6\% increase in soluble solids of tomato fruit in FMVC plots compared with control treatment. However, maximum titrable acidity $(0.0081 \mathrm{mg}$ citric acid/100g) in fruit juice was found in MVC plots. TN (Total Nitrogen) concentration of tomato fruit juice was increased by $1.74 \%$ in with FMVC over control treatments. Maximum lycopene contents $\left(22.19 \mathrm{mg} \mathrm{kg}^{-1}\right)$ were observed in FMVC plots as compared to all other treatments. It could be concluded that all treatments improved growth, yield and quality of fruit compared with control; whereas FMVC treatment performed better.
\end{abstract}

Key Words: Compost, Farm Manure, Sugarcane Waste Material, Tomato, Vermi-Compost, Fruit Quality.

\section{INTRODUCTION}

$\mathrm{S}$ oil fertility is critical to crop yield, which is dependent upon several controls such as environmental conditions [1], agrochemicals and nutrients used, organic amendments (e.g. farm and green manures) and soil biota [2]. The soil biological health is one of the dominant factors, which significantly contributes to the maintenance of soil fertility and crop yield. Dumping of organic wastes is becoming a challenge for many countries as use of raw organic wastes could deteriorate environment [3], soil and plants health due to the presence of undesirable pathogens and toxic substances [4]. It has been frequently documented that organic wastes should be recycled using composting and vermi-composting techniques prior to their use in cultivated soils [5]. This technique could reduce the environmental hazards and maintain the sustainable agriculture by providing soil organic matter and mineral nutrition [6].

Composting being an environment friendly strategy not only helps in protecting the environment but also

\footnotetext{
${ }^{1}$ Department of Soil Science, Faculty of Agricultural Sciences and Technology, Bahauddin Zakariya University, Multan, Pakistan. Email: ${ }^{\mathrm{a}}$ rahmatshah78@yahoo.com (Corresponding Author), ${ }^{\mathrm{b}}$ muhammadabid@bzu.edu.pk, cFarooq.qayyum@bzu.edu.pk
}

This is an open access article published by Mehran University of Engineering and Technology, Jamshoro under CC BY 4.0 International License. 
produces the best soil amendments [7] for achieving desired soil properties. Thus, application of composts as a soil amendment has multiple benefits such as improving the soil health, minimizing the disease threat and controlling the soil erosion [8]. Moreover, the organic material mineralization improves nutrient availability, which in turn improves crop yield [9]. Vermi-compost materials are produced through the effective interaction of microbes and earthworms that could be used to improve the soil fertility [7]. During the vermi-composting, microbes are mainly involved in biochemical decomposition of organic matter; whereas earthworms drive the process by acclimatizing the substrate [10]. The end product, i.e. vermi-compost serves as a soil conditioner [11]. The vermi-compost material is reported to boost the availability of mineral nutrients including nitrogen (five folds), phosphorus (seven folds), potassium (eleven folds) and magnesium (two folds) in the soil [12]. There are reports that earthworms are helpful for replacing harmful insects and bio-accumulating heavy metals during the vermi-composting process [13].

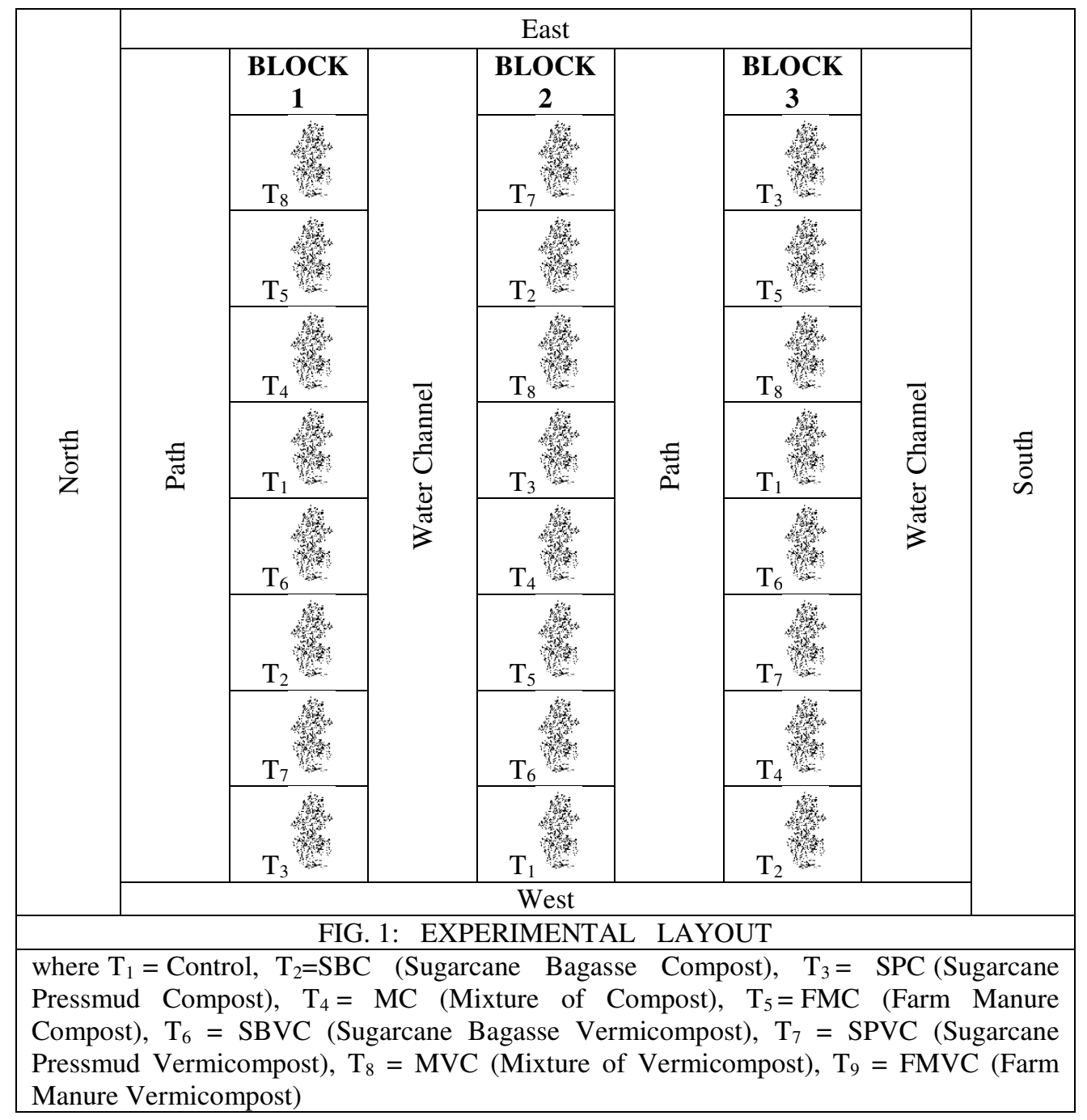

Increase in growth, yield and quality of tomato fruits are reported as a result of vermi-composting in pot and field experiments [14]. Higher contents of $\mathrm{Ca}$ and and vitamin $\mathrm{C}$ in tomato fruits have also been observed with vermi-compost application [15]. The With vermi-compost application [15]. The $\quad$ Pakistan, little work has been done on using local composition of compost also affect the yield of crops such as tomato [9]. It has been reported that an application of vermi-compost enhances soil fertility [16] by providing with essential nutrient [17]. In Pakistan, little work has been done on using local 
species of earthworms for preparation of vermicompost. As for as we know that compost and vermicompost of sugarcane industrial wastes and farm manure for safe utilization have rarely been reported.

Therefore, we investigated the effects of compost and vermi-compost made from sugarcane industrial wastes and farm manure on the growth, yield and carbohydrate concentration, total nitrogen, lycopene contents, soluble and insoluble solids of tomato fruits.

\section{MATERIALS AND METHOD}

\subsection{Preparation of Compost and Vermi- Compost}

Organic wastes, including sugarcane bagasse, press mud, effluent and farm manure were used for composting and vermi-composting. The detailed procedure for preparation of compost and vermicompost and their analyses have been discussed earlier [18].

\section{Experimental Layout:}

The experimental field located at Research Area of Bahauddin Zakariya University, Multan, Pakistan was ploughed with disc harrow and then cultivator followed with planking was used to prepare the field. A total of 27 plots (each of $1 \mathrm{~m}^{2}$ ) were made manually. The plots were applied with triplicate of nine treatments (including control): sugar SBC (Cane Bagasse Compost), SPC (Sugarcane Press Mud Compost), mixture [SB $\times \mathrm{SP} \times \mathrm{SE}$ (Sugarcane Effluent)] of compost (MC), FMC and four vermi-compost, i.e. SBVC (Sugar Cane Bagasse Vermin-Compost), SPVC (Sugarcane Press Mud Vermin-Compost), mixture $(\mathrm{SB} \times \mathrm{SP} \times \mathrm{SE})$ of vermi-compost (MVC), FMVC @ $10 \mathrm{t} \mathrm{ha}^{-1}$. The basal NPK fertilizers @ 2776-76 $\mathrm{kg} \mathrm{ha}^{-1}$ were applied by using urea, diammonium phosphate and sulphate of potash. The composts were mixed well and two raised beds of each $0.4 \mathrm{~m}(0.2 \mathrm{~m}$ spacing was maintained between the beds) were prepared in each plot. Treatments were arranged according to randomized complete block design with three replications. Two healthy forty-five days old tomato seedlings were transplanted on each bed at $30 \mathrm{~cm}$ plant to plant distance. After 15 days of transplanting, the plants were thinned out to one per hole, thus total 12 plants were maintained in each plot. Underground water was used for irrigation $[\mathrm{EC}=0.67$ $\left.\mathrm{dS} \mathrm{m}{ }^{-1} ; \mathrm{SAR}=3.0 \mathrm{mmol} \mathrm{L}^{-1} ; \mathrm{RSC}=\mathrm{Nil}\right]$. Total 12 irrigations were applied. Weed control, hoeing, insect and pest control, etc. were done as per recommendation of local area. The crop was grown up to maturity and plant height, stem diameters and numbers of leaves were recorded at 25 DAT (Days After Transplanting); thereafter every seven days up to 100 days.

Numbers of fruits and their weight were recorded from each plot. Fruits having marketable and nonmarketable quality (cracked, damaged and infected) were graded. However, marketable fruits were taken to determine the yield and quality. Tomato fruit-yield was taken at 85 and 100 DAT. The soil samples taken from the 27 experimental plots (before application of treatments) were thoroughly mixed and a representative composite sample was prepared. The sample was analyzed following standard analytical method by [19]. The physicochemical properties of the composite sample are provided in Table 1.

\subsection{Chemical Analyses of Tomato Fruit}

For fruit quality analysis, tomato fruits from each treatment were cut into small slices and then mixed. Juice of fruit was extracted by hand pressing $10 \mathrm{~g}$ sub samples through cheese cloth. The $\mathrm{Ph}[20]$, soluble solids (\%) [21], titrable acidity (mg citric acid/100g) total nitrogen [21] of tomato fruit was measured. Acidity of tomato juice was measured in mg citric acid per $100 \mathrm{Ml}$ [22]. Lycopene contents $\left(\mathrm{mg} \mathrm{kg}^{-1}\right)$ of tomato juice were also measured. Lycopene contents were calculated by the formula [23].

$$
\begin{aligned}
\text { Lycopene } \mathrm{mg} \mathrm{kg}^{-1} & =\left[\frac{\mathrm{A}_{503} \times 537 \times 8 \times 0.55}{0.10 \times 172}\right] \times 1 \\
= & A_{503} \times 137.4
\end{aligned}
$$

where $537 \mathrm{~g} / \mathrm{mol}=$ Molecular weight of lycopene, $8 \mathrm{~mL}=$ Volume of mixed solvent $0.10 \mathrm{~g}=$ Tomato weight $172 \mathrm{mM}-1=$ Extinction coefficient for lycopene in hexane. 


\begin{tabular}{|c|c|}
\hline \multicolumn{2}{|c|}{$\begin{array}{c}\text { TABLE 1. PHYSICO-CHEMICAL } \\
\text { PROPERTIES OF THE EXPERIMENTAL SITE }\end{array}$} \\
\hline Soil Characteristics & \\
\hline $\mathrm{pH}_{\mathrm{s}}$ & 8.1 \\
\hline EC & $2.01\left(\mathrm{dS} \mathrm{m}^{-1}\right)$ \\
\hline Moisture contents & $13.24(\%)$ \\
\hline Soil texture & Silt Loam \\
\hline $\mathrm{BD}$ & $1.571\left(\mathrm{Mg} \mathrm{m}^{-3}\right)$ \\
\hline SOM & $0.59(\%)$ \\
\hline MBC & $134\left(\mu \mathrm{g} \mathrm{g}^{-1}\right)$ \\
\hline MBN & $5.21\left(\mu \mathrm{g} \mathrm{g}^{-1}\right)$ \\
\hline Total soil nitrogen & $0.04(\%)$ \\
\hline Available soil potassium & $164\left(\mu \mathrm{g} \mathrm{g}^{-1}\right)$ \\
\hline Available soil phosphorous & $16.81\left(\mu \mathrm{g} \mathrm{g}^{-1}\right)$ \\
\hline $\begin{array}{l}\text { where BD (Bulk Density), } \\
\text { Carbon), MBC (Microbial Bi } \\
\text { (Microbial Biomass Nitrogen) } \\
\text { Matter) }\end{array}$ & $\begin{array}{l}\text { (Soil Organic } \\
\text { s Carbon) MBN } \\
\text { M (Soil Organic }\end{array}$ \\
\hline
\end{tabular}

\subsection{Statistical Analyses}

Analysis of variance using randomized complete block design was performed using Statistix 8.1 (a computer-based software). The comparisons among treatments were made following tukey-honestly significant difference test at $\mathrm{P} \leq 0.05$ [24].

\section{RESULTS AND DISCUSSION}

\subsection{Growth, Yield and Yield Components}

Compost and vermin-compost treatments significantly increased $(\mathrm{p} \leq 0.05)$ tomato plant height (Fig.2). Initially, all treatments did not affect plant height significantly from 25-32 DAT. The FMVC treatment produced taller tomato plants as compared to all other treatments. Plant height increased slightly during 2532DAT; significantly between 39-53 DAT; slightly increased during 60-81 DAT and very slightly during 88-100 DAT. The plant height was 37, 35, 23, 22, 15, 14, 10, 9 and 8\% in FMVC, FMC, SPVC, SPC, MVC, MC, SBVC and SBC, respectively compared with control.

Application of FMVC, MVC, SCPV, SBVC, FMC, MC, SPC and SBC significantly $(\mathrm{p} \leq 0.05)$ increased stem diameter of tomato plant (Fig. 3). There was more increase in stem diameter in FMVC plots as compared to other treatments. In general, stem diameter increased very slightly during 25-32 DAT;

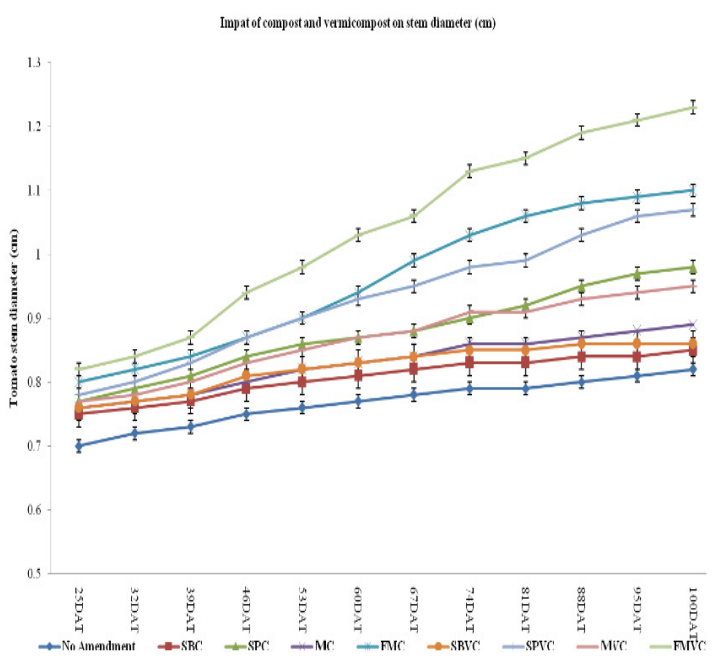

FIG. 2. EFFECT OF COMPOST AND VERMICOMPOST TREATMENT ON PLANT HEIGHT [WHERE:SBC (SUGARCANE BAGASSE COMPOST), SPC (SUGARCANE PRESSMUD COMPOST), MC (MIXTURE OF COMPOST), FMC (FARM MANURE COMPOST), SBVC (SUGARCANE BAGASSE VERMICOMPOST), SPVC (SUGARCANE PRESSMUD VERMICOMPOST), MVC (MIXTURE OF VERMICOMPOST) AND FMVC (FARM MANURE VERMICOMPOST.BARS INDICATE THE STANDARD ERROR)]

then maximum increased between 39-74 DAT and then again very slightly during 81-100 DAT. In this study, stem diameter was enhanced by FMVC $(0.82-$ $1.23 \mathrm{~cm})$ followed by FMC (0.86-1.10), SPVC $(0.78-$ $1.07 \mathrm{~cm}), \operatorname{SPC}(0.77-0.98 \mathrm{~cm})$, MVC $(0.77-0.95 \mathrm{~cm})$, MC $(0.76-0.89 \mathrm{~cm}), \operatorname{SBVC}(0.76-0.86 \mathrm{~cm}), \mathrm{cm}), \mathrm{SBC}$ $(0.75-0.86 \mathrm{~cm})$ and control $(0.70-0.82 \mathrm{~cm})$.

The number of leaves per tomato plant increased significantly $(\mathrm{p} \leq 0.05)$ with compost and vermincompost of different organic wastes (Fig.4). Application of FMCV increased more number of leaves (34\%) over the control treatment. There was a significant $(\mathrm{p} \leq 0.05)$ effect of treatments on number of fruits per plant (Fig.5). The FMVC treatment increased maximum (34) number of fruits per plant followed by FMC (30), SPVC (28.6), SPC (26.6), MVC (24), MC (22.7), SBVC (22), SBC (21.7) and control (20.3). The FMVC increased $40 \%$ number of fruits per plant over control treatment. 




FIG. 3. EFFECT OF COMPOST AND VERMICOMPOST TREATMENT ON PLANT STEM DIAMETER [WHERE: SBC (SUGARCANE BAGASSE COMPOST), SPC (SUGARCANE PRESSMUD COMPOST), MC (MIXTURE OF COMPOST), FMC (FARM MANURE COMPOST), SBVC (SUGARCANE BAGASSE VERMICOMPOST), SPVC (SUGARCANE PRESSMUD VERMICOMPOST), MVC (MIXTURE OF VERMICOMPOST) AND FMVC (FARM MANURE VERMICOMPOST)]

All treatments showed significant $(\mathrm{p} \leq 0.05)$ effect on tomato fruit weight. Maximum fruit weight was noted in FMVC treatment (46.33 g) followed by FMC (44.33 g), SCPV (40.70 g), SPC (37.70 g), MVC (34.67 g), $\mathrm{MC}(32.00 \mathrm{~g})$, SBVC (31.33 g), SBC (29.66 g) and control $(28.00 \mathrm{~g})$. The fruit weight was increased by
$39 \%$ with FMVC over control treatment. The yield was found to be highest $\left(0.98 \mathrm{t} \mathrm{ha}^{-1}\right)$ with FMVC; while the lowest in control $\left(0.50 \mathrm{t} \mathrm{ha}^{-1}\right)$. Similarly, SBC, SPC, MC, FMC, SBVC, SPVC and MVC treatments produced yield $0.77,0.87,0.82,0.93,0.79$, 0.89 and $0.84 \mathrm{tha}^{-1}$, respectively.

Results reported in Figs. 2-3, illustrated that FMVC increased plant height and stem diameter over all other treatments. This could be due to increased $\mathrm{P}$ and $\mathrm{K}$ uptake and availability of earthworm casts (efficient source of plant nutrients) in the vermin-compost [25]. Data presented in this study are in accordance with those of [26], who reported that growth and yield of tomato was increased with application of vermincompost made from pig manure.

Results reported herein also agree with MarquezHernandez et al. [27]. However, Moreno-Reséndez et. al. [28] reported that vermin-compost did not affect tomato stem diameter and plant height. They concluded that application of four types of vermincompost of horse manure, goat manure; alfalfa straw and garden-waste have the potential of high moisture retention capacity in soil. Results of this study regarding increment in a number of leaves of tomato are similar to Sundararasu et. al. [29]. However, Abduli et. al. [30] reported a positive effect of vermincompost on tomato plant. Results reported in Fig. 4 indicated that number of fruits and their weights were higher with FMVC treatment. It might be due to the liberation of maximum nutrient availability in soil

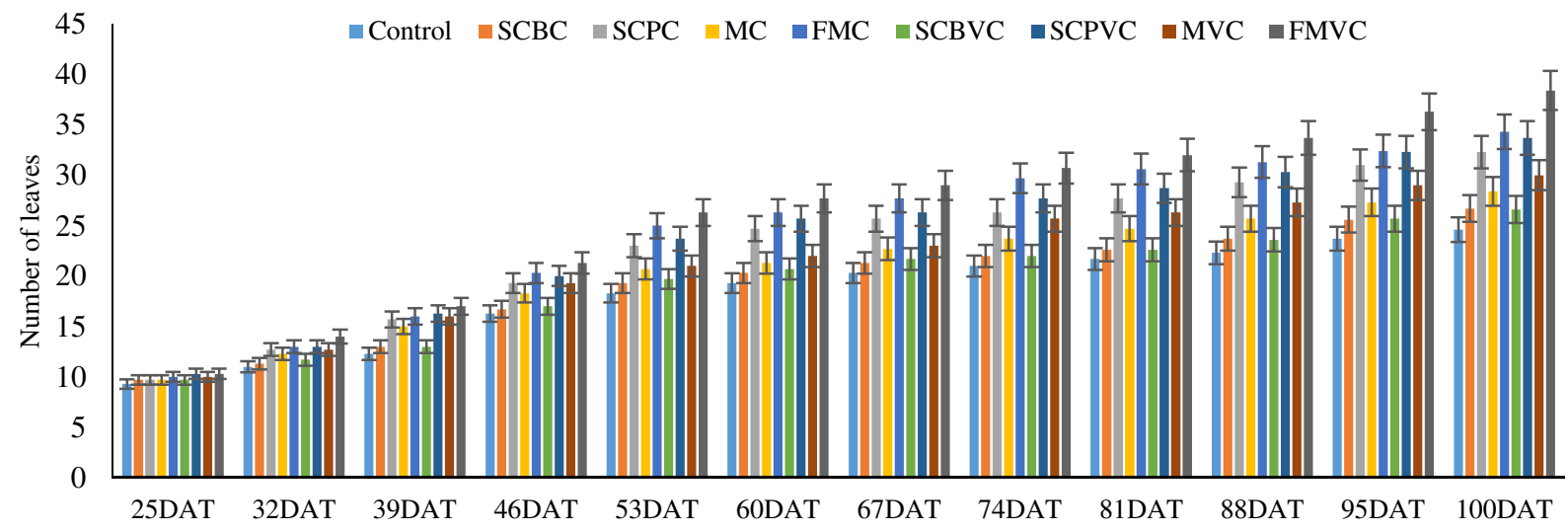

FIG. 4. EFFECT OF COMPOST AND VERMICOMPOST TREATMENT ON NUMBER OF LEAVES PER PLANT [WHERE:SBC (SUGARCANE BAGASSE COMPOST), SPC (SUGARCANE PRESSMUD COMPOST), MC (MIXTURE OF COMPOST), FMC (FARM MANURE COMPOST), SBVC (SUGARCANE BAGASSE VERMICOMPOST), SPVC (SUGARCANE PRESSMUD VERMICOMPOST), MVC (MIXTURE OF VERMICOMPOST) AND FMVC (FARM MANURE VERMICOMPOST).

Mehran University Research Journal of Engineering and Technology, Vol. 39, No. 2, April 2020 [p-ISSN: 0254-7821, e-ISSN: 2413-7219] 


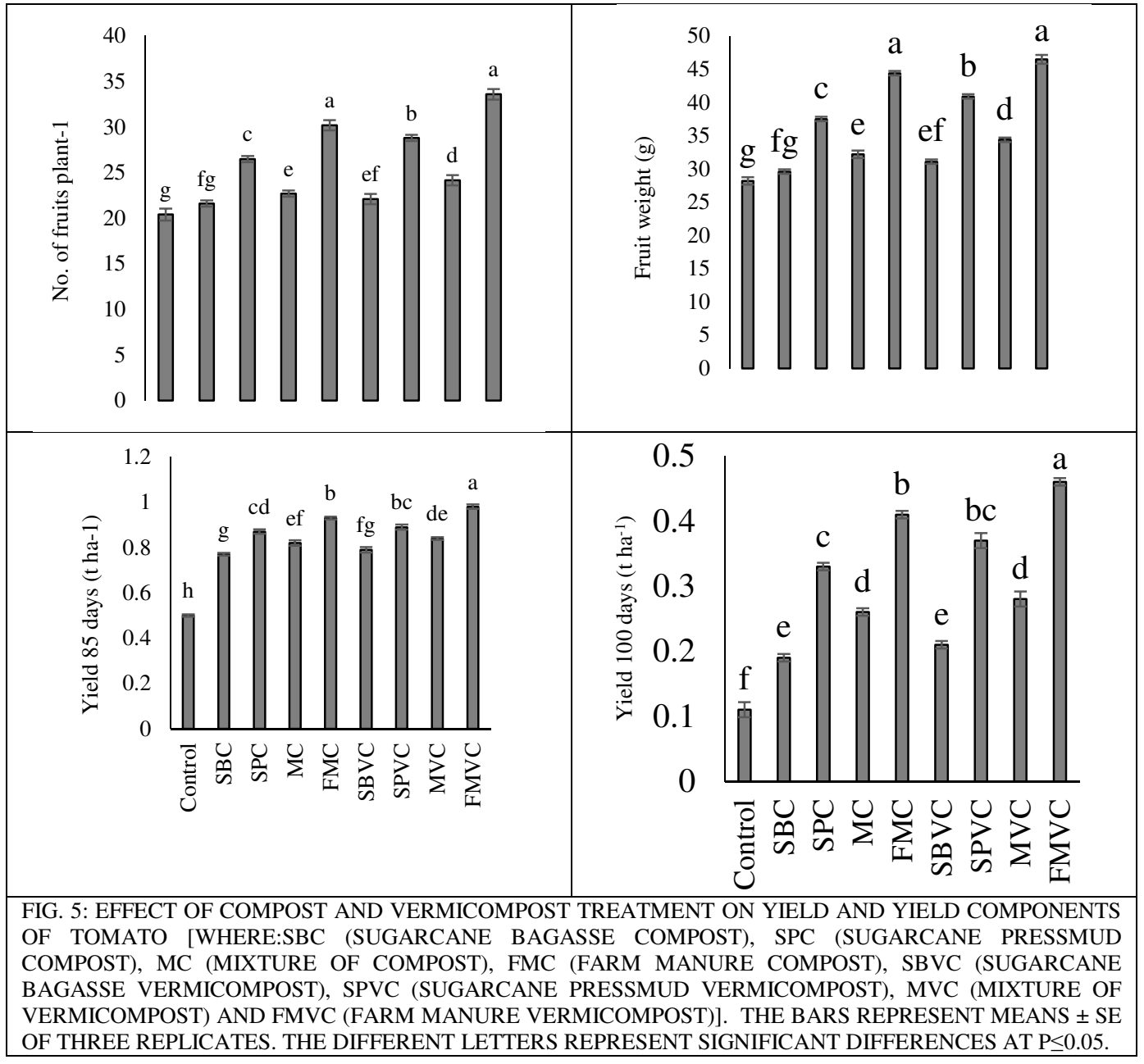

through vermin-composting [31]; improving enzyme activation for flower induction and fruit setting [32]; correlative abscission of young fruit would lead to higher tomato fruit production [33]. Samawat et. al. [34] reported more tomato fruit weight, fruit number, shoot weight and root weight with vermin-compost treated plants. Singh et. al. [35] reported $93.6 \mathrm{~g}$ more fruit weight when FM vermin-compost @ 7.50 tha $^{-1}+$ NPK @ 60-30-30 kg ha ${ }^{-1}$ compared with NPK @ 12060-60 kgha $^{-1}$ treatment without vermin-compost (83.1g). Our data indicated that FMVC produced higher yield ( 0.98 and $\left.0.43 \mathrm{tha}^{-1}\right)$ than other treatments after 85 and 100 DAT (Fig. 5). Various studies on vermin-composting revealed the significant improvement in tomato yield [11-26]. Similarly, Prativa et. al. [36] reported $15 \%$ more fruit weight withvermin-compost @ $20 \mathrm{mt} \mathrm{ha}^{-1}$ as compared to control treatment.

\subsection{Quality of fruits}

Tomato fruit quality was significantly $(p \leq 0.05)$ improved with FMVC, MVC, SCPV, SBVC, FMC, MC, SPC and SBC amendments (Fig. 6). However, the acidity in tomato fruit juice in terms of $\mathrm{pH}$ value was significantly higher in FMVC $(\mathrm{pH}$ 3.97) treatment followed by FMC (4.03), MVC (4.07), MC (4.07), SPC (4.13), SPVC (4.17), SBVC \& SBC (4.47) and control (4.57) treatment. The SBVC and SBC remained at par with each other for $\mathrm{pH}$ in tomato fruit juice. The FMVC treatment had increased 13\% more acidity over control treatment.

Soluble solids were significantly $(\mathrm{p} \leq 0.05)$ affected with application of all treatments. However, soluble solids were produced maximum $(6.15 \%)$ in FMVC while minimum $(4.47 \%)$ in control treatment. TA Mehran University Research Journal of Engineering and Technology, Vol. 39, No. 2, April 2020 [p-ISSN: 0254-7821, e-ISSN: 2413-7219] 
(Titrable Acidity) in tomato fruit was significantly $(p \leq 0.05)$ affected with all treatments similar to the findings of Ahmad et. al. [37]. Maximum value was found in MVC $(0.0081 \mathrm{mg}$ citric acid $/ 100 \mathrm{~g})$ followed by MC $(0.008 \mathrm{mg}$ citric acid/100g), FMVC $(0.0079$ $\mathrm{mg}$ citric acid/100g), FMC (0.0078 mg citric acid/100g), SPVC (0.0076 mg citric acid/100g), SPC (0.0075 mg citric acid/100g), SBVC $(0.0072 \mathrm{mg}$ citric $\mathrm{acid} / 100 \mathrm{~g})$, SBC $(0.0071 \mathrm{mg}$ citric acid/100g) and control treatment $(0.007 \mathrm{mg}$ citric acid/100g).

Addition of compost and vermin-compost improved TN content in tomato fruit (Fig. 6). The TN was observed maximum (1.74\%) in FMVC and minimum $(1.59 \%)$ in control treatment. Similarly, all treatments also affected significantly the lycopene contents in fruit juice. Lycopene content was more in FMVC (22.19 $\left.\mathrm{mg} \mathrm{kg}^{-1}\right)$ followed by FMC (21.16 $\left.\mathrm{mg} \mathrm{kg}^{-1}\right)$, SPVC (19.74 $\left.\mathrm{mg} \mathrm{kg}^{-1}\right)$, SPC (19.01 $\left.\mathrm{mg} \mathrm{kg}^{-1}\right)$, MVC (18.10 mg kg-1), MC (17.73 mg kg-1), SBVC (16.57 $\left.\mathrm{mg} \mathrm{kg}^{-1}\right), \mathrm{SBC}\left(15.87 \mathrm{mg} \mathrm{kg}^{-1}\right)$ and control (13.99 mg $\mathrm{kg}^{-1}$ ) plots. However, in FMVC treatment fruit juice was acidic, TN, lycopene contents and soluble solids were more as compared to other treatments. TA was higher $\left(0.0081 \mathrm{mg}\right.$ citric acid100 $\left.^{-1}\right)$ in $\mathrm{MVC}$ as compared to control.

Our data is similar to the results of Joshi et. al. [38], who reported that vermi-compost of cattle dung with soil increased soluble solids $45 \%$ than control and decreased TA $34 \%$ than control. Similarly, Chatterjee et. al. [39] reported that vermin-compost improved lycopene (4.51 mg $100 \mathrm{~g}^{-1}$ ) over control (4.46 mg 100 $\left.\mathrm{g}^{-1}\right)$ and nitrate contents improved $\left(42.07 \mathrm{~g} \mathrm{~kg}^{-1}\right)$ over control $\left(33.48 \mathrm{~g} \mathrm{~kg}^{-1}\right)$ in tomato juice. Various research articles on tomato plants report that vermin-compost improves tomato fruiting [11-14], root development [40], fruit color [35] and shelf life and quality of the economic produce [41].

\section{CONCLUSION}

It is concluded that the FM (Farm Manure) using local earthworm species produced a higher quality organic fertilizer that had positive influence on plant growth and fruit quality of tomato plants. In future, more extensive experiments could be conducted using tested organic materials and local earthworm species for preparation of vermi-compost and to study their influence on various soil physico-chemical properties as well as growth and yield of different crops.

\section{ACKNOWLEDGMENT}

This research study is the part of Ph.D. Dissertation of first author, which was sponsored by Higher Education Commission, Islamabad, Pakistan under "HEC indigenous Ph.D. Fellowship Program".

\section{REFERENCES}

[1] Granath, G., Rydin, H., Baltzer, J. L., Bengtsson, F., Boncek, N., Bragazza, L., Bu, Z.J., Caporn, S.J., Dorrepaal, E., Galanina, O., Gałka, M., Ganeva, A., Gillikin, D. P., Goia, I., Goncharova, N., Hájek, M., Haraguchi, A., Harris, L.I., Humphreys, E., Jiroušek, M., Kajukało, K., Karofeld, E., Koronatova, N. G., Kosykh, N. P., Lamentowicz, M., Lapshina, E., Limpens, J., Linkosalmi, M., Ma, J.Z., Mauritz, M., Munir, T.M., Natali, S. M., Natcheva, R., Noskova, M., Payne, R. J., Pilkington, K., Robinson, S., Robroek, B. J. M., Rochefort, L., Singer, D., Stenøien, H. K., Tuittila, E. S., Vellak, K., Verheyden, A., Waddington, J. M., and Rice, S. K., "Environmental and Taxonomic Controls of Carbon and Oxygen Stable Isotope Composition in Sphagnum Across Broad Climatic and Geographic Ranges", Biogeosciences, Vol. 15, 51895202.2018

[2] Khadka, B., Munir, T. M., and Strack, M., "Dissolved Organic Carbon in a Constructed and Natural Fens in the Athabasca Oil Sands Region, Alberta, Canada", Science of The Total Environment, Vol. 557, 579-589. 2016.

[3] Khoso, A. R.,Memon, A. H., Pathan, A. A., and Akhund, M. A., "Solid Waste Management Issues in Hyderabad City", Mehran University Research Journal of Engineering \& Technology, Vol. 37, No. 3, 653-662. 2018.

[4] Westerdahl, B., "Biological Control of PlantParasitic Nematodes: Soil Ecosystem Management in Sustainable Agriculture", Soil Science Society of America Journal, Vol. 79, No.3, pp.972, 2015. 




[5] Theunissen, J., Ndakidemi, P.A., and Laubscher, C.P., "Potential of Vermicompost Produced from Plant Waste on the Growth and Nutrient Status in Vegetable Production", International Journal of Physical Sciences, Vol. 5, No.13, pp. 19641973, 2010.

[6] Mal, S., "Compost Quality Assessment for Successful Organic Waste Recycling", Development, Vol. 25, pp.27, 2013.

[7] Lannan, A.P., Erich, M.S., and Ohno, T., "Compost Feedstock and Maturity Level Affect Soil Response to Amendment", Biology and Fertility of Soils, Vol. 49, No.3, pp.273-285, 2013. 
[8] Crohn, D.M., Chaganti, V.N., and Reddy, N., "Composts as Post-Fire Erosion Control Treatments and Their Effect on Runoff Water Quality", Transactions of the ASABE, Vol. 56, No.2, pp.423-435, 2013.

[9] Traversa, A., Loffredo, E., Palazzo, A.J., Bashore, T.L., and Senesi, N., "Enhancement of Germination and Growth of Slickspot Peppergrass in a New Medium with Two Compost Organic Fractions". Communications in Soil Science and Plant Analysis, Vol. 44, No.17, pp. 26362646, 2013.

[10] Whalen, J.K., Kernecker, M.L., Thomas, B.W., Ngosong, C., and Sachdeva, V., "Soil Food Web Controls on Nitrogen Mineralization are Influenced by Agricultural Practices in Humid Temperate Climates". CAB Reviews, Vol. 8, No.23, pp.1-18, 2013.

[11] Zaller, J.G., "Vermicompost as a substitute for peat in potting media. Effects on Germination, Biomass Allocation, Yields and Fruit Quality of Three Tomato Varieties", ScientiaHorticulturae, Volume 112, No.2, pp.191-199, 2007.

[12] Bridgens, S., "The Importance of Earthworms", Span. Vol. 22, No.8, pp.2040,1981.

[13] Sinha, R.K., Herat, S., Bharambe, G., and Brahambhatt, A., "Vermistabilization of Sewage Sludge (Biosolids) by Earthworms: Converting a Potential Biohazard Destined for Landfill Disposal into a Pathogen-Free, Nutritive and Safe Biofertilizer for Farms", Waste Management \& Research, Vol. 28, No.10, pp.872-881, 2010.

[14] Gutiérrez-Miceli, F.A., Santiago-Borraz, J., Molina, J.A.M., Nafate, C.C., Abud-Archila, M., Llaven, M.A.O., Rincon-Rosales, R., and Dendooven, L., "Vermicompost as a Soil Supplement to Improve Growth, Yield and Fruit Quality of Tomato (Lycopersicum esculentum)", Bioresource Technology, Vol. 98, No.15, pp. 2781-2786, 2007.

[15] Premuzic, Z., Bargiela, M., Garcia, A., Rendina, A., and Iorio, A., "Calcium, Iron, Potassium,Phosphorus and Vitamin C Content of Organic and Hydroponic Tomatoes", HortScience, Vol. 33, No. 2, pp.255-257,1998.

[16] Ceritoğlu, M., Şahin, S., and Erman, M., "Effects of Vermicompost on Plant Growth and Soil Structure", Selçuk Tarımve Gıda
Bilimleri Dergisi, Vol. 32, No.3, pp.607615, 2018.

[17] Bhat, S.A., Singh, S., Singh, J., Kumar, S. and Vig, A.P., "Bioremediation and Detoxification of Industrial Wastes by Earthworms: Vermicompost as Powerful Crop Nutrient in Sustainable Agriculture. Bioresource Technology, Vol. 252, pp.172-179, 2018.

[18] Shah, R.U., Abid, M., Qayyum, M. F., and Ullah, R., "Dynamics of Chemical Changes through Production of Various Composts/Vermicompost such as Farm Manure and Sugar Industry Waste", International Journal of Recycling of Organic Waste in Agriculture, Vol. 4, No.1, pp. 39-51, 2015.

[19] Ryan, J., Estefan, G., and Rashid, A., "Soil and Plant Analysis Laboratory Manual", International Center for Agricultural Research in the Dry Areas (ICARDA), Second Edition, 2007.

[20] Thomas, G.W., "Soil pH and Soil Acidity. In: Methods of soil analyses, Part 3, sparks, D.L. (Ed.). Chemical Methods", Soil Science Society of America Inc., American Society of Agronomy, Inc., Madison, WI. pp: 475-490, 1996.

[21] Gutiérrez-Miceli, F.A., Santiago-Borraz, J., Molina, J.A.M., Nafate, C.C., Abud-Archila, M., Llaven, M.A.O., Rincon-

Rosales, R., and Dendooven, L., "Vermicompost as a Soil Supplement to Improve Growth, Yield and Fruit Quality of Tomato (Lycopersicum esculentum)", Bioresource Technology, Vol. 98, No.15, pp. 2781-2786, 2007.

[22] Wang, S.Y., and Lin, S.S., "Compost as Soil Supplement Enhanced Plant Growth and Fruit Quality of Strawberry", Journal of Plant Nutrition, Vol. 25, No. 10, pp.2243-2259, 2002.

[23] Davis, A.R., Fish, W.W.,and Perkins-Veazie, P.,"A Rapid Hexane Free Method for AnalyzingLycopene Content in Watermelon", Journal of Food Science, Vol. 68, No.1, pp. 328-332, 2003.

[24] McGraw-Hill, C. Statistix 8.1. Analytical Software, Tallahassee, FL, USA. 2008.

[25] Chaoui, H.I., Zibilske, L.M., and Ohno, T., "Effects of Earthworm Casts and Compost on Soil Microbial Activity and Plant Nutrient Availability",Soil Biology and Biochemistry, Vol. 35, No. 2, pp. 295-302, 2003. 
[26] Atiyeh, R.M., Arancon, N., Edwards, C.A., and Metzger, J.D., "Influence of EarthwormProcessed Pig Manure on the Growth and Yield of Greenhouse Tomatoes", Bioresource Technology, Vol. 75, No. 3, pp.175-180, 2000.

[27] Márquez Hernández, C., Cano Ríos, P., and Rodríguez Dimas, N., "Uso de Sustratos Orgánicos Para la Producción de Tomate en Invernadero", Agricultura Técnica en México, Vol. 34, No. 1, pp. 69-74, 2008.

[28] Moreno Reséndez, A., and Valdés Perezgasga, M.T., "Desarrollo de Tomate en Sustratos de Vermicompost/Arena bajoCondiciones de Invernadero", Agricultura Técnica, Vol. 65, No.1, pp.26-34, 2005.

[29] Sundararasu, K., and Neelanarayanan, P.,"Effect of Vermicompost and Inorganic Fertilizer on the Growth and Yield of Tomato, Lycorpersicum esculentum L", International Journal of Current Research, Vol. 4, No. 07, pp. 49-51, 2012.

[30] Abduli, M.A., Amiri, L., Madadian, E., Gitipour, S., and Sedighian, S., "Efficiency of Vermicompost on Quantitative and Qualitative Growth of Tomato Plants", International Journal of Environmental Research, Vol. 7, No. 2, pp. 467-472, 2013.

[31] Lazcano, C., Arnold, J., Zaller, J.G., Martín, J.D., and Salgado, A.T., "Compost and Vermicompost as Nursery Pot Components: Effects on Tomato Plant Growth and Morphology". Spanish Journal of Agricultural Research, Vol. 4, pp. 944-951, 2009.

[32] Khalid, S., Qureshi, K.M., Hafiz, I.A., Khan, K.S., and Qureshi, U.S., "Effect of Organic Amendments on Vegetative Growth, Fruit and Yield Quality of Strawberry", Pakistan Journal of AgriculturalResearch, Vol. 26, No. 2, 2013.

[33] Atiyeh, R.M., Domínguez, J., Subler, S., and Edwards, C.A., "Changes in Biochemical Properties of Cow Manure during Processing by Earthworms (Eiseniaandrei, Bouché) and the Effects on Seedling Growth", Pedobiologia, Vol. 44, No. 6, pp. 709-724, 2000.
[34] Samawat, S., Amir, L., and Zamirpour, A.R., "The Effect of Vermicompost on Growth Characteristicsof Tomato", Agricultural Science and Technology, Vol. 15, No. 2, pp. 83-89, 2001.

[35] Singh, B., Pathak, K., Boopathi, T., and Deka, B., "Vermicompost and NPK Fertilizer Effects on Morpho-Physiological Traits of Plants, Yield and Quality of Tomato Fruits: (Solanumlycopersicum 1.)", Vegetable Crops Research Bulletin, Vol. 73, pp. 77-86, 2010.

[36] Prativa, K. C., and Bhattarai, B.P.,"Effect of Integrated Nutrient Management on the Growth, Yield and Oil Nutrient Status in Tomato", Nepal Journal of Science and Technology, Vol. 12, pp. 23-28, 2012.

[37] Ahmad, I., Bibi, F., Ullah H, and Munir, T., "Mango Fruit Yield and Critical Quality Parameters Respond to Foliar and Soil Applications of Zinc and Boron", Plants, Vol. 7, No. 4, pp. 97, 2018.

[38] Joshi, R., and Vig, A.P., "Effect of vermicompost on growth, yield and quality of tomato (Lycopersicum esculentum L)", African Journal of Basic and Applied Science, Vol. 2, No. 3-4, pp. 117-123, 2010.

[39] Chatterjee, R., Jana, J.C., and Paul, P.K., "Vermicompost Substitution Influences Shelf Life and Fruit Quality of Tomato (Lycopersicon esculentum Mill.)", American Journal of Agricultural Science and Technology, Vol. 1, pp. 69-76, 2013.

[40] Dobbss, L.B., Pasqualoto Canellas, L., Lopes Olivares, F., Oliveira Aguiar, N., Peres, L.E.P., Azevedo, M., Spaccini, R., Piccolo, A., and Façanha, A.R.,"Bioactivity of Chemically Transformed Humic Matter from Vermicompost on Plant Root Growth", Journal of Agricultural and Food Chemistry, Volume 58, No. 6, pp.3681-3688, 2010.

[41] Roy, S., Kumar, N., Singh, D.K., and Srivastava, A.K., "Effect of Organic Growing Media and Crop Geometry on Growth and Yield of Capsicum var. California Wonder under Protected Condition in North West Himalayas", Vegetable Science, Volume 38, No. 1, pp. 53-57, 2011. 